\title{
Proportion of injured alcohol-impaired drivers subsequently convicted of an impaired driving criminal code offence in British Columbia
}

\author{
Roy A. Purssell, MD; ${ }^{*}$ Mark Yarema, MD; ${ }^{\dagger}$ Jean Wilson, PhD; ${ }^{\ddagger}$ Ming Fang, MA;§ \\ Richard Simons, MD; II Sharon Kasic, CCHRA(C); ${ }^{* *}$ Riyad B. Abu-Laban, MD, MHSc; ${ }^{\dagger \dagger}$ \\ Jeffrey Brubacher, MD; ${ }^{\dagger+}$ Ioana Lupu, BSc ${ }^{\S \S}$
}

Early online release, published at www.caep.ca on Feb. 18, 2004.

\begin{abstract}
Background: Alcohol is a frequent contributing factor to motor vehicle collision injuries. Our objective was to determine the proportion of intoxicated drivers hospitalized following motor vehicle crashes who were subsequently convicted of an impaired driving criminal code offence.

Methods: We reviewed British Columbia Trauma Registry records from Jan. 1, 1992, to Mar. 31, 2000, and identified drivers of motor vehicles who were hospitalized for treatment of crash-related injuries. Patient identifiers were then used to link with the Insurance Corporation of British Columbia's (ICBC) contraventions database and the ICBC Traffic Accident System collisions database.

Results: Of 6067 patients identified in the Trauma Registry, 4042 had not been administered a blood ethanol test, 209 had no driver's licence match in the relevant databases and 119 died, leaving 1697 eligible patients. Mean age was 34 years, and $79.6 \%$ were male. The average Injury Severity Score was 20, the average hospital stay was 14 days and, among ethanol-positive patients, the mean ethanol level was $34.0 \mathrm{mmol} / \mathrm{L}(156.4 \mathrm{mg} / \mathrm{dL})$. In patients with levels $>17.3$ $\mathrm{mmol} / \mathrm{L}$, the police had listed ethanol as a contributing factor in $70.6 \%$ of cases. Despite this, only $11.0 \%$ were convicted of impaired driving and $8.4 \%$ of another criminal offence; $10.7 \%$ received a 24 -hour roadside prohibition, $3.9 \%$ received a 90 -day administrative driving prohibition and $25.0 \%$ were convicted of a contravention of the Motor Vehicle Act. Forty-one percent were not convicted of any offence at all.

Conclusions: Intoxicated drivers in British Columbia requiring hospitalization as a result of alcohol-related motor vehicle crashes are seldom convicted of impaired driving or other criminal code offences.
\end{abstract}

\footnotetext{
*Head, Department of Emergency Medicine, Vancouver Hospital; Associate Professor, University of British Columbia, Vancouver, BC †Medical Toxicology Fellow, Banner Good Samaritan Medical Center, Phoenix, Ariz.

¥Manager, Road Safety Research, Insurance Corporation of British Columbia, North Vancouver, BC

§Road Safety Research, Insurance Corporation of British Columbia

I Trauma Director, Vancouver Hospital; Associate Professor, Department of Surgery, University of British Columbia

** Manager, BC Trauma Registry

†† Staff Emergency Physician, Vancouver Hospital; Assistant Professor, Division of Emergency Medicine, Department of Surgery, University of British Columbia

$\ddagger \ddagger$ Staff Emergency Physician, Vancouver Hospital; Clinical Associate Professor, Division of Emergency Medicine, Department of Surgery, University of British Columbia and the Vancouver General Hospital Center for Clinical Epidemiology and Education, Vancouver, BC $\S \S$ Medical Student, University of British Columbia
}

Received: Nov. 5, 2003; final submission: Dec. 1, 2003; accepted: Dec. 3, 2003

This article has been peer reviewed.

Can J Emerg Med 2004;6(2):80-8 
Key words: alcohol, ethyl, blood; automobile driving, alcoholic intoxication, blood; accidents, traffic RÉSUMÉ

Contexte : L'alcool joue souvent un rôle dans les collisions de la route avec blessés. Notre objectif était de déterminer la proportion de conducteurs intoxiqués qui furent hospitalisés à la suite d'accidents de la route et subséquemment condamnés pour conduite avec facultés affaiblies.

Méthodes : Nous avons examiné les dossiers du Registre des traumatismes de la Colombie-Britannique du $1^{\text {er }}$ janvier 1992 au 31 mars 2000 et identifié les conducteurs d'automobile hospitalisés pour traitement de blessures liées à un accident de la route. Les identificateurs de patients furent ensuite utilisés pour accéder à la banque de données de I'Insurance Corporation of British Columbia (ICBC) et la banque de données sur les collisions du Traffic Accident System de I'ICBC.

Résultats : Parmi 6067 patients identifiés à partir du Registre des traumatismes, 4042 n'avaient pas subi d'alcootest, le nom de 209 d'entre eux n'apparaissait pas dans les banques de données pertinentes pour les permis de conduire et 119 moururent, laissant 1697 patients admissibles. L'âge moyen des patients était de 34 ans et 79,6 \% étaient de sexe masculin. L'indice moyen de la gravité des blessures était de 20, la durée d'hospitalisation moyenne était de 14 jours et parmi les patients dont l'alcootest était positif, le taux moyen d'éthanol était de $34,0 \mathrm{mmol} / \mathrm{L}(156,4 \mathrm{mg} / \mathrm{dL})$. Chez les patients dont le taux était supérieur à $17,3 \mathrm{mmol} / \mathrm{L}$, la police avait noté l'alcool comme un facteur ayant contribué à l'accident dans $70,6 \%$ des cas. Malgré cela, seulement $11 \%$ de ces patients furent condamnés pour conduite avec facultés affaiblies et $8,4 \%$ pour une autre infraction criminelle; 10,7 \% écopèrent d'une [interdiction de conduire pendant 24 heures], 3,9\% écopèrent d'une interdiction de conduire pendant 90 jours et $25,0 \%$ furent condamnés pour une infraction au Motor Vehicle Act. Quarante et un pour cent ne reçurent aucune sorte de condamnation.

Conclusions : Les conducteurs intoxiqués de la Colombie-Britannique devant être hospitalisés à la suite d'accidents de la route sont rarement condamnés pour conduite avec facultés affaiblies ni pour toute autre infraction criminelle.

\section{Introduction}

Motor vehicle crashes are the leading cause of death for persons aged 15 to 29 years. ${ }^{1,2}$ In 2001 in Canada there were 867 alcohol-related motor vehicle fatalities, and $32.1 \%$ of fatally injured drivers were legally impaired. ${ }^{3}$ In $71 \%$ of cases, the drivers had blood alcohol levels greater than $32.6 \mathrm{mmol} / \mathrm{L}(150 \mathrm{mg} / \mathrm{dL})$ - almost twice Canada's legal limit of $17.3 \mathrm{mmol} / \mathrm{L}$. Blood alcohol concentration (BAC) is strongly correlated with crash likelihood and crash severity; depending on age, a driver with a blood alcohol level of $17.4-21.7 \mathrm{mmol} / \mathrm{L}(80-100 \mathrm{mg} / \mathrm{dL})$ is 11 to 52 times more likely to be involved in a fatal motor vehicle crash than a driver with no BAC. ${ }^{4,5}$ At levels of 32.6 $\mathrm{mmol} / \mathrm{L}(150 \mathrm{mg} / \mathrm{dL})$, a fatal motor vehicle crash is 250 times more likely. ${ }^{6}$

Studies from the United States and Sweden show highly variable conviction rates for intoxicated drivers brought to emergency departments (EDs) for treatment of crash-related injuries, ${ }^{7-13}$ and some authors suggest that the hospital is a legal safe haven for impaired drivers. ${ }^{9}{ }^{14}$ If this is true, it suggests the need for system change to address this major public health threat; however, there are no published Canadian data describing conviction rates of injured drivers with known BACs.
Our objective was to determine the percentage of hospitalized drivers with blood alcohol levels $>17.3 \mathrm{mmol} / \mathrm{L}$ ( 80 $\mathrm{mg} / \mathrm{dL}$ ) who were subsequently convicted of impaired driving. This information has implications for ED processes, legislative policy and law enforcement practice.

\section{Methods}

\section{Setting and patients}

In this retrospective British Columbia study, we reviewed data submitted by the 6 participating hospitals to the $\mathrm{BC}$ Trauma Registry. All patients who were the drivers of motor vehicles involved in crashes and who were admitted to a participating hospital for treatment of injuries between Jan. 1, 1992, and Mar. 31, 2000, were eligible for inclusion. Patients were excluded if they did not have a blood ethanol determination, if we could not match their records using a valid $\mathrm{BC}$ driver's licence, or if they died.

\section{Outcomes}

The key predictor variable studied was BAC; the test for BAC is performed in the participating hospitals' laboratories as one of the standard investigations specified in a guideline for care of trauma patients in BC. Under the Criminal Code of Canada it is an offence to drive with a 
BAC $>17.3 \mathrm{mmol} / \mathrm{L}(80 \mathrm{mg} / \mathrm{dL})$; therefore, to assess the relationship between BAC and legal outcome we stratified patients into 3 groups: $\mathrm{BAC}=$ zero $\mathrm{BAC}=1-17.3$ $\mathrm{mmol} / \mathrm{L}$; and $\mathrm{BAC}>17.3 \mathrm{mmol} / \mathrm{L}$.

The primary outcome variable studied was the rate of impaired driving criminal code convictions in different blood alcohol strata. Because multiple legal consequences may arise from a single incident, each study patient was assigned the single highest relevant "conviction outcome" based on the following hierarchy: impaired driving criminal code conviction; other criminal code conviction; 90-day administrative driving prohibition; 24hour roadside prohibition; other Motor Vehicle Act offence; no conviction.

\section{Data capture}

BC Trauma Registry data included patient demographics, collision mechanism, hospital length of stay and Injury Severity Score, which was calculated on all patients with a length of stay $>2$ days. Trauma Registry data were obtained from 6 hospitals: 3 hospitals contributed data for the entire study period, 1 contributed data from 1993 to 2000, and 2 contributed only for 2000 .

To link patients to clinical data and contraventions we obtained relevant drivers' licence numbers from the Insurance Corporation of British Columbia (ICBC) business information warehouse or the ICBC Traffic Accident System (police-reported collisions database). Using the driver's licence number, birthdate, gender, name and incident date, we linked Trauma Registry data with the ICBC contraventions database, which records all convictions for criminal code driving offences and Motor Vehicle Act offences in BC. A margin of \pm 3 days was permitted in incident date to allow for possible errors in data recording. If no match was found for the incident date, we assumed that no conviction or prohibition had resulted.

\section{Data analysis}

Descriptive statistics, including rates, means and standard deviations, were used to quantify outcome events in the study population.

\section{Ethics and confidentiality}

The data-sharing protocol was developed by the Manager of the BC Trauma Registry and approved by the Director of the Registry, the trauma directors of all participating hospitals, and the information security officer of Vancouver Hospital, the lead hospital, and was provided to ICBC's Information Risk Management Department. The information sharing agreement was developed using guidelines from the BC Freedom of Information legislation. Information sharing was in one direction only. Records containing personal information maintained by ICBC were not released or shared. The study was approved by the University of British Columbia and all participating hospitals' ethics committees.

\section{Results}

The BC Trauma Registry identified 6067 drivers hospitalized for the treatment of motor vehicle related injuries during the study period. Of these, the files of 4042 patients did not include a blood ethanol result, 209 patients could not be linked to a valid driver's licence, and 119 patients died, leaving 1697 patients in the study sample. Most were male (79.6\%), and the mean age was 34 years (range 14-93 yr). Two-thirds of the collisions involved automobiles, and $13.9 \%$ involved motorcycles. Of automobile drivers, $69 \%$ were reported to have been wearing a seatbelt.

Table 1 shows patient characteristics classified by BAC. Overall, the mean BAC was $16.2 \mathrm{mmol} / \mathrm{L}(74.5 \mathrm{mg} / \mathrm{dL})$ with a range of $0-88.2 \mathrm{mmol} / \mathrm{L}$. For ethanol-positive patients, the mean BAC was $34 \mathrm{mmol} / \mathrm{L}(156.4 \mathrm{mg} / \mathrm{dL})$. Sin-

Table 1. Characteristics of the study population

\begin{tabular}{lcccc} 
& \multicolumn{4}{c}{ No. of patients (and \%)* } \\
\cline { 2 - 5 } & $\begin{array}{c}\mathrm{BAC}=0 \\
\mathrm{mmol} / \mathrm{L}\end{array}$ & $\begin{array}{c}\mathrm{BAC}=1-17.3 \\
\mathrm{mmol} / \mathrm{L}\end{array}$ & $\begin{array}{c}\mathrm{BAC}=>17.3 \\
\mathrm{mmol} / \mathrm{L}\end{array}$ & Total \\
\hline Total & $898(52.9)$ & $180(10.6)$ & $619(36.5)$ & $1697(100)$ \\
Men & $686(76.4)$ & $153(85.0)$ & $511(82.6)$ & $1350(79.6)$ \\
Age, mean (and SD) & $36(16.1)$ & $31(13.3)$ & $32(11.4)$ & $43(14.4)$ \\
Single-vehicle crash & $346(38.5)$ & $98(54.4)$ & $415(67.0)$ & $859(50.6)$ \\
Mean ISS (and SD) & $20(14)$ & $21(14)$ & $19(13)$ & $20(13)$ \\
Hospital LOS, mean & & & & $12(22)$ \\
$\quad$ (and SD) & $14(21)$ & $17(28)$ & $12(21)$ & $14(22)$ \\
\hline *Unless otherwise specified. & & & \\
BAC= blood alcohol concentration; SD = standard deviation; LOS = length of stay in days \\
\hline
\end{tabular}


gle-vehicle accidents, which comprised $50 \%$ of the total, were almost twice as frequent in intoxicated versus non-intoxicated drivers (67\% v. 38.5\%). Mean Injury Severity Score in the study sample was 20 (range 1-75), and patients spent a mean of 14 days (range $0-238 \mathrm{~d}$ ) in hospital.
Twenty percent were cared for in the intensive care unit an average of 9 days. Figure 1 illustrates the age distribution of intoxicated and non-intoxicated patients in the study sample, and Figure 2 and Figure 3 show the temporal clustering of accidents by hour of day and by day of the week.

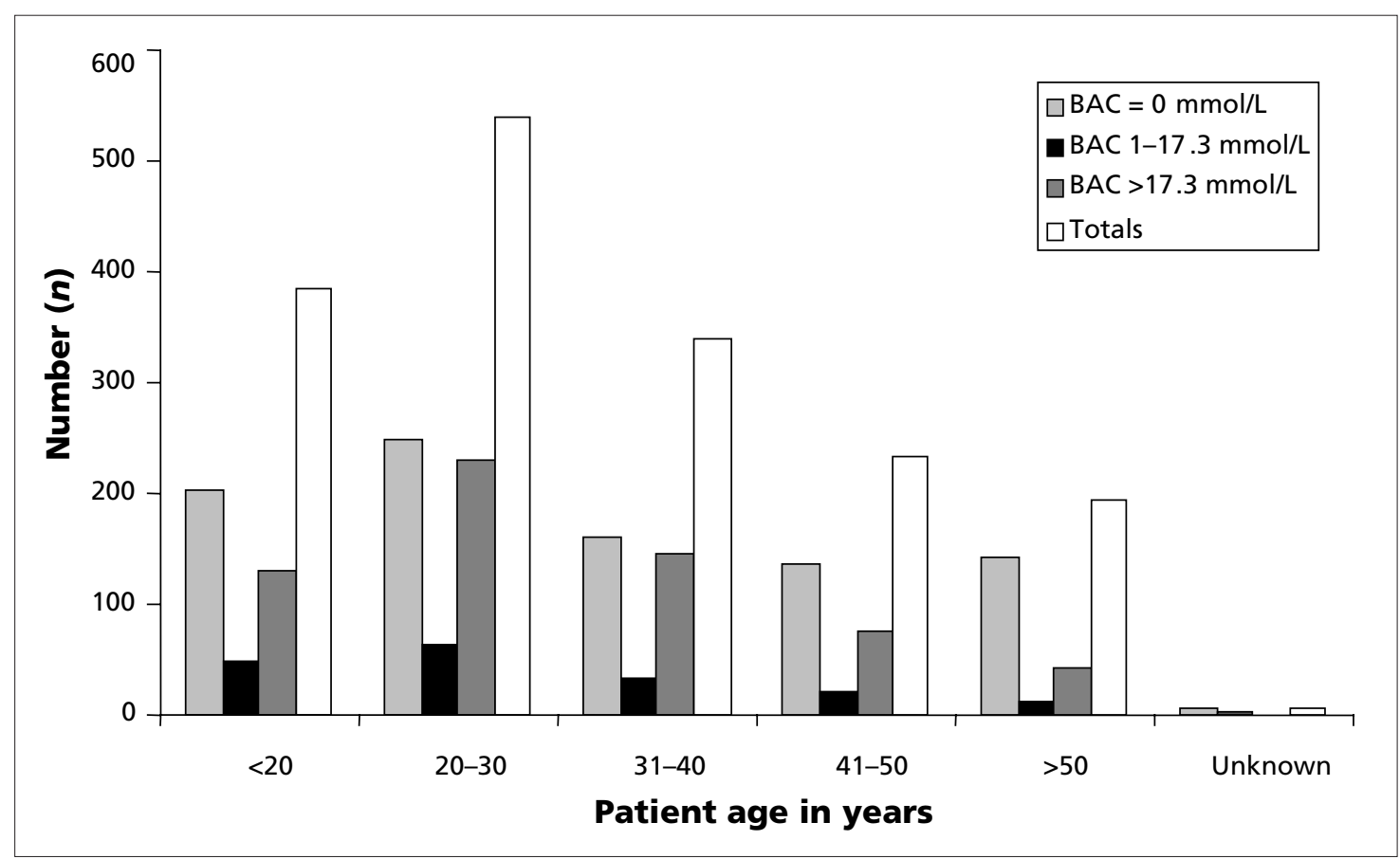

Fig. 1. Age distribution of eligible study patients. $B A C=$ blood alcohol concentration.

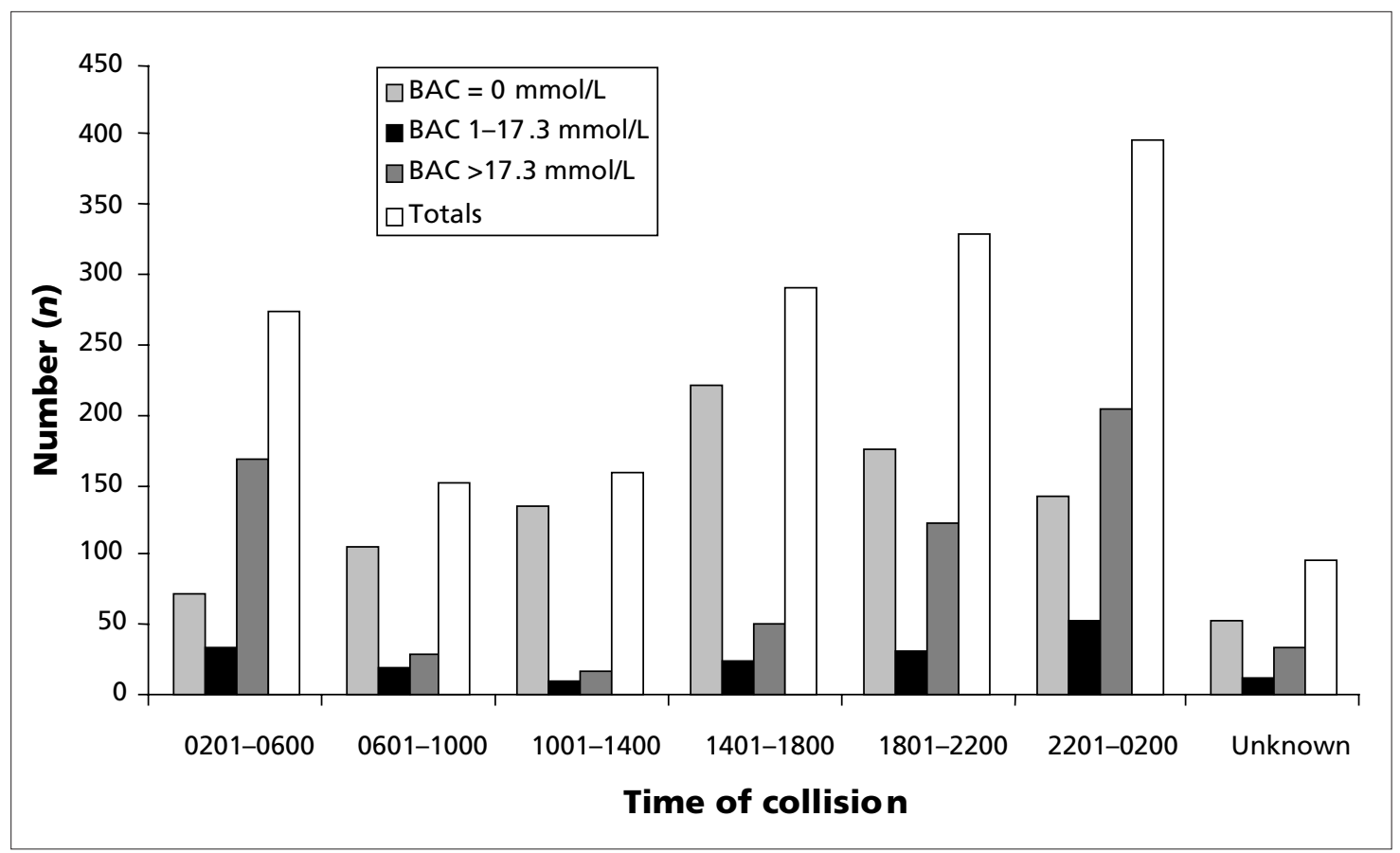

Fig. 2. Time of collision occurrence. $B A C=$ blood alcohol concentration. 
Based on police accident reports, alcohol use was the most common contributory factor, cited in $31.7 \%$ of all injury accidents and in $70.5 \%$ of cases where the driver's BAC was subsequently found to be $>17.3 \mathrm{mmol} / \mathrm{L}$ ( 80 $\mathrm{mg} / \mathrm{dL}$ ). Table 2 shows that $59.0 \%$ of injured drivers with $\mathrm{BAC}>17.3 \mathrm{mmol} / \mathrm{L}$ received some type of sanction, most often a contravention of the Motor Vehicle Act, but that only 120 of $619(19.4 \%)$ were convicted under the criminal code $-11.0 \%$ for impaired driving and $8.4 \%$ for another criminal code offence. Over the 8 years of the study, criminal code conviction rates for intoxicated drivers ranged from a low of 14\% (11 of 77) in 1999 to a high of $29 \%$ (16 of 56) in 1993, with no clear trend over time. Table 2 also shows that some drivers received impaired driving penalties despite very low BACs, possibly due to impairment by drugs other than alcohol.
Table 3 summarizes the legal outcomes in cases where police cited alcohol as a contributory factor versus cases they did not. Of note, criminal code convictions occurred in only $22 \%$ of cases where alcohol was cited as a contributory factor, and there were non-alcohol-related traffic convictions or no legal consequences in $60.4 \%$ of cases.

\section{Discussion}

In this large cohort of alcohol-impaired drivers admitted to hospital, $11 \%$ were convicted of an impaired driving criminal code offence and $8.4 \%$ of another criminal code offence; $41 \%$ had no conviction, $10.7 \%$ received a 24 -hour roadside suspension and $25 \%$ were convicted only of a Motor Vehicle Act traffic offence. Previous studies from the US and Sweden show widely variable impaired driving

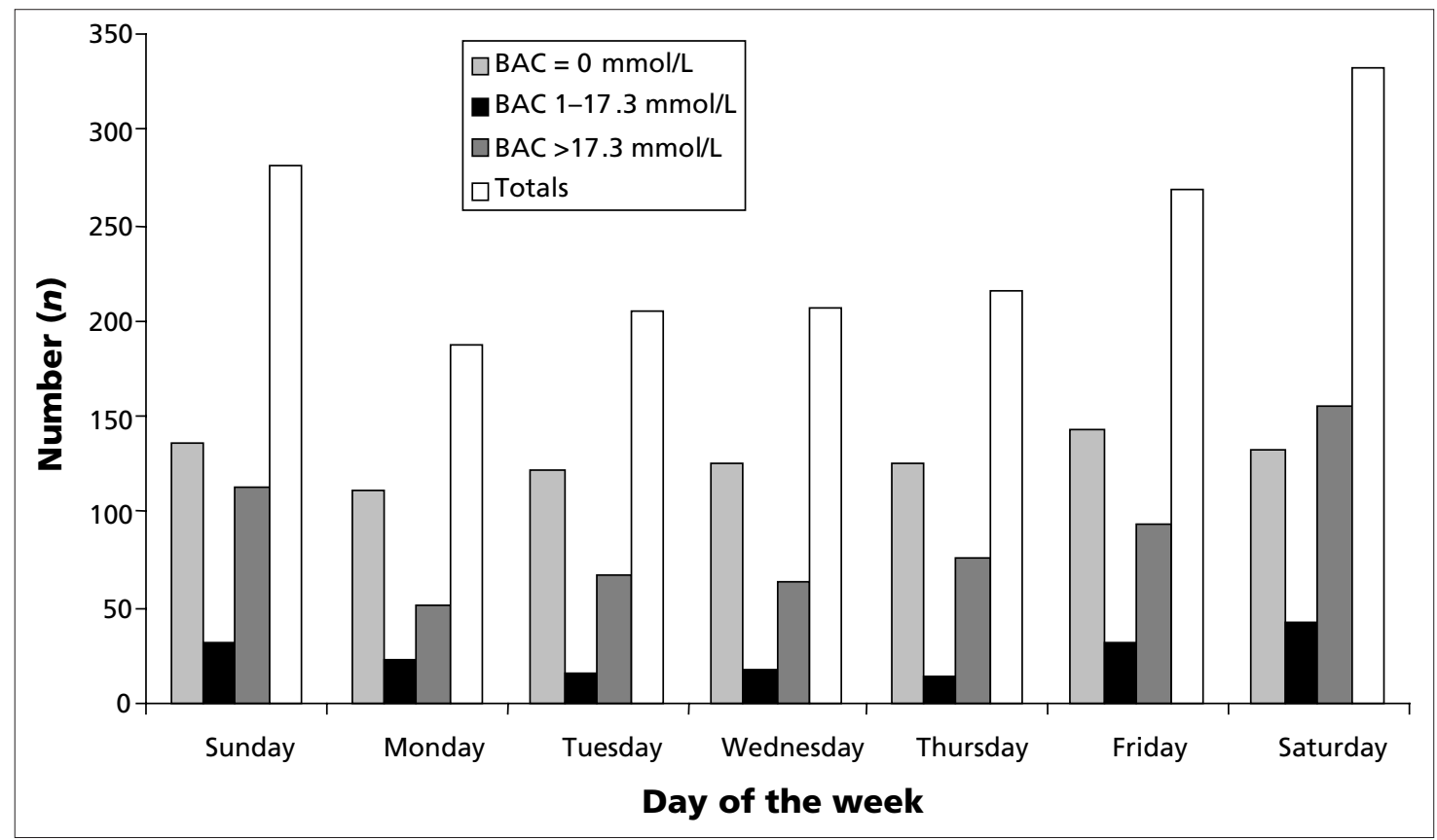

Fig. 3. Day of the week for collisions. BAC = blood alcohol concentration.

Table 2. Legal outcomes for injured drivers stratified by blood alcohol concentration (BAC)

\begin{tabular}{|c|c|c|c|c|c|c|c|}
\hline \multirow[b]{3}{*}{$\mathrm{BAC}, \mathrm{mmol} / \mathrm{L}$} & \multicolumn{7}{|c|}{ Type of conviction, no. of drivers (and \%) } \\
\hline & \multicolumn{2}{|c|}{ Criminal code conviction } & \multirow{2}{*}{$\begin{array}{c}\text { 90-day } \\
\text { administrative } \\
\text { driving } \\
\text { prohibition }\end{array}$} & \multirow{2}{*}{$\begin{array}{l}\text { 24-hour } \\
\text { roadside } \\
\text { prohibition }\end{array}$} & \multirow{2}{*}{$\begin{array}{l}\text { Other Motor } \\
\text { Vehicle Act } \\
\text { contravention }\end{array}$} & \multirow[b]{2}{*}{$\begin{array}{c}\text { No } \\
\text { conviction }\end{array}$} & \multirow[b]{2}{*}{ Total } \\
\hline & $\begin{array}{l}\text { Impaired } \\
\text { driving }\end{array}$ & Other & & & & & \\
\hline Zero & $7(0.8)$ & $17(1.9)$ & $1(0.6)$ & $5(0.6)$ & $229(25.5)$ & $639(71.2)$ & 898 \\
\hline $1-17.3$ & $2(1.1)$ & $10(5.5)$ & $1(0.6)$ & $3(1.7)$ & $43(24.0)$ & $121(67.2)$ & 180 \\
\hline$>17.3$ & $68(11.0)$ & $52(8.4)$ & $24(3.9)$ & $66(10.7)$ & $155(25.0)$ & $254(41.0)$ & 619 \\
\hline Total & $77(4.5)$ & $79(4.7)$ & $26(1.5)$ & $74(4.4)$ & $427(25.2)$ & $1014(59.8)$ & 1697 \\
\hline
\end{tabular}


conviction rates by setting, ranging from $0 \%$ in 3 US studies published prior to 1992 to $85 \%$ in a recent Swedish study. ${ }^{7-18}$ The impaired driving conviction rate in this Canadian study is below the median rate of $15.5 \%$ found among the 12 published studies listed in Table 4 . These low conviction rates may reduce the legal deterrent to drinking and driving.

\section{Why are conviction rates so low?}

Some authors have demonstrated dramatically higher conviction rates for impaired drivers who were not taken to hospital and concluded that the hospital may be a legal safe haven for impaired drivers; ${ }^{9,14}$ however, a recent study by Wilson and Fang suggests that conviction rates in BC are almost as low for uninjured drivers. ${ }^{19}$ These authors examined all police reports and collision records from 2000 and found that, of 1876 cases where police judgement (not alcohol testing) suggested alcohol was a contributory factor, there were 1238 injured and 638 uninjured drivers. In Wilson and Fang's study, $15.4 \%$ of injured drivers and $18.8 \%$ of uninjured drivers were convicted of a criminal code driving offence, confirming that, in $\mathrm{BC}$, relatively few individuals are convicted of impaired driving, regardless of whether or not they are taken to the hospital with an injury.

\section{Possible explanations}

There are 2 possible explanations for low conviction rates

\begin{tabular}{|c|c|c|c|}
\hline \multirow[b]{2}{*}{ Legal outcome } & \multicolumn{3}{|c|}{$\begin{array}{l}\text { Contributing factors, } \\
\text { no. of drivers (and \%) }\end{array}$} \\
\hline & Alcohol* & Non-alcohol & Total \\
\hline $\begin{array}{l}\text { Criminal code conviction: } \\
\text { impaired }\end{array}$ & $47(11.5)$ & $2(1.2)$ & $49(8.4)$ \\
\hline $\begin{array}{l}\text { Criminal code conviction: } \\
\text { other }\end{array}$ & $43(10.5)$ & $6(3.5)$ & $49(8.4)$ \\
\hline $\begin{array}{l}\text { 90-day administrative } \\
\text { driving prohibition }\end{array}$ & $22(5.4)$ & $0(0.0)$ & $22(3.8)$ \\
\hline $\begin{array}{l}\text { 24-hour roadside } \\
\text { prohibition }\end{array}$ & $50(12.2)$ & $2(1.2)$ & $52(9.0)$ \\
\hline $\begin{array}{l}\text { Other Motor Vehicle Act } \\
\text { contravention }\end{array}$ & $115(28.0)$ & $55(32.2)$ & $170(29.3)$ \\
\hline No contraventions & $133(32.4)$ & $106(62.0)$ & $239(41.1)$ \\
\hline Total & $410(100.0)$ & $171(100.0)$ & $581(100.0)$ \\
\hline
\end{tabular}

\begin{tabular}{|c|c|c|c|c|}
\hline Author(s) & $\begin{array}{l}\text { Year of } \\
\text { study }\end{array}$ & $\begin{array}{c}\text { Setting, US } \\
\text { state* }\end{array}$ & $\begin{array}{l}\text { No. of study } \\
\text { subjects }\end{array}$ & $\begin{array}{c}\text { Convictions, } \\
\% \\
\end{array}$ \\
\hline Maull et $\mathrm{al}^{7}$ & 1984 & Virginia & 56 & 0 \\
\hline Colquitt et $\mathrm{al}^{8}$ & 1987 & Connecticut & 59 & 0 \\
\hline Soderstrom et al $^{9}$ & 1990 & Maryland & 58 & 12.1 \\
\hline Fantus et al $^{15}$ & 1991 & Illinois & 116 & 0 \\
\hline McLaughlin et al $^{16}$ & 1992 & Michigan & 49 & 59.2 \\
\hline Rehm et al $^{17}$ & 1993 & New Jersey & 87 & 14.0 \\
\hline Barillo $^{18}$ & 1993 & Pennsylvania & 480 & 40.6 \\
\hline 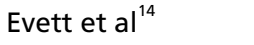 & 1994 & Virginia & 245 & 3.7 \\
\hline Runge et $\mathrm{al}^{10}$ & 1996 & North Carolina & 187 & 17.0 \\
\hline Cydulka et al ${ }^{11}$ & 1998 & Ohio & 78 & 21.0 \\
\hline Krause et al ${ }^{12}$ & 1998 & Michigan & 71 & 51.0 \\
\hline Mattsson et al ${ }^{13}$ & 2000 & Umea, Sweden & 15 & 85.0 \\
\hline
\end{tabular}


of injured alcohol-impaired drivers. Either these drivers are not charged with impaired driving, or they are charged but not convicted. Our study cannot answer this question because we identified only drivers who were convicted, not those charged; however, other recent data suggest the primary problem is a low rate of charging impaired drivers with criminal code offences. Linguanti ${ }^{20}$ reported that between 1989 and 1997 the number of alcohol-related criminal charges in BC fell from 14350 to 8294 - a $42 \%$ decrease. During this time, the conviction rate for drivers charged with impaired driving remained relatively constant, but the number of 24-hour roadside prohibitions increased 37\%, from 29820 to $40971 .{ }^{20}$ A BC Ministry of Public Safety and Solicitor General 2003 Discussion Paper confirmed that between 1995 and 2001 the number of impaired driving charges recommended by police decreased by $20 \%$ and the number of 24-hour driving prohibitions increased by $13 \% .^{21}$

\section{Reasons identified by police}

BC's 2000 Traffic Services Study survey ${ }^{22}$ asked police to identify reasons they are reluctant to recommend more severe criminal charges. Three primary reasons surfaced: the time required to process the charge; insufficient staff to process the impaired driver; and the belief that the impaired driver would not be found guilty or would plead to a lesser offence such as careless driving. In fact, the process involved in charging an individual with impaired driving is so complex and time-consuming that police officers often issue a violation ticket or a 24-hour prohibition instead of an impaired driving charge.

A 1996 survey of 1545 Canadian police officers found that it takes an average of 2 hours and 48 minutes to process each impaired driving charge, that officers must complete an average of 8 forms for each charge, and that the average impaired driving trial takes over 4 hours. ${ }^{23}$ Most of the officers felt that crown attorneys are inadequately prepared for impaired driving cases and agreed that, although convicting impaired drivers is a priority, the human resources available to do so are inadequate.

\section{Other barriers}

There are other reasons why so few injured, intoxicated drivers are charged. One possible barrier is that police may have limited access because injured drivers are being resuscitated, sent to other parts of the hospital for imaging, or rushed to the operating room; but, at least in our setting, most patients stay in the ED long enough for police to initiate criminal charges. And although medical care takes precedence, it is our practice to provide police easy access to these patients.

A second potential barrier to criminal charges is that, especially in seriously injured drivers, police officers may have difficulty determining whether or not a driver is intoxicated. However, in our cohort of ethanol-positive patients, the average ethanol level was $34 \mathrm{mmol} / \mathrm{L}$ (156.4 $\mathrm{mg} / \mathrm{dL}$ ), and it seems unlikely that police officers would fail to recognize this degree of intoxication. Further, in the group of drivers who were legally intoxicated based on subsequent alcohol testing, police officers correctly cited alcohol as a contributing factor in over $70 \%$ of these cases.

A third barrier, and perhaps the most important, is a challenging and often impracticable array of legal prerequisites that may deter police officers from demanding blood samples..$^{24}$ To illustrate, officers may demand blood alcohol testing only if they can demonstrate reasonable grounds to believe a suspect has committed an impaired driving offence within 3 hours and that the suspect is incapable of providing a breath sample. For suspects who are capable of providing breath samples, the difficulty involved in transporting a technician and breath-testing equipment to the hospital is obvious.

\section{Can we increase conviction rates?}

Convicting impaired drivers has several beneficial effects for the community. The two most obvious of these are that dangerous drivers are removed from the road for a significant period of time (a minimum of 1 year in $\mathrm{BC}$ ) and that conviction of impaired drivers probably serves as a deterrent to others. There is also evidence that loss of driving privileges encourages individuals to curtail drinking-driving behaviour and reduces subsequent episodes of dangerous driving, motor vehicle crashes and driving violations. ${ }^{25}$ Convicted drivers can be ordered to attend alcohol-abuse treatment programs, and every Canadian province except $\mathrm{BC}^{*}$ has a mandatory rehabilitation program for such drivers. These programs significantly reduce subsequent drinking-driving convictions and crashes. ${ }^{21}$

\section{Other countries}

Other jurisdictions have implemented more aggressive measures to increase conviction rates. In Sweden, police officers may demand blood samples from any patient suspected of impaired driving. This system appears to be effective, as evidenced by $85 \%$ conviction rates for injured intoxicated drivers. ${ }^{13}$ In the state of Victoria (Australia),

*A June 2003 Discussion Paper by the BC government contains a proposal for a mandatory assessment and treatment program. ${ }^{21}$ 
legislation requires that medical staff take blood ethanol samples from all occupants of a vehicle involved in a motor vehicle crash and provide these results to the patients and the police. Conviction rates for injured, intoxicated drivers in this jurisdiction are over 90\% (Dr. Ron Christie, RCSC Services Pty Ltd, Burwood, Victoria, Australia: personal communication, 2003).

\section{Canada's Road Safety Vision 2010}

Canada unveiled a national strategy called "Road Safety Vision 2010," which was adopted by the Canadian Council of Motor Transport Administrators and officially endorsed by all ministers of Transportaion and Highways Safety in 1996, to achieve the safest roads in the world by 2010. ${ }^{26}$ One of the objectives is a $40 \%$ reduction in the number of people killed or seriously injured in alcohol-related crashes. The Road Safety Vision recommendations would streamline procedures for processing impaired drivers, encourage officers to lay more criminal code charges rather than imposing short-term suspensions, and improve education for police, justice departments and the judiciary on the nature and management of drinking and driving. In recent years, 5 Canadian provinces have instituted alcohol/ignition interlock programs, under which specified drivers are given a device that, when wired to their vehicle's ignition system, prevents it from being started if the driver is intoxicated. Such devices decrease driving-while-intoxicated recidivism, ${ }^{27,28}$ but methods of increasing program participation must be found because, typically, less than $10 \%$ of offenders opt to have a device installed. ${ }^{29}$

\section{What is the role of the ED?}

A recent review at our institution found that $8.6 \%$ of all ED visits were directly related to misuse of drugs or alcohol. ${ }^{30}$ In other settings, the prevalence of alcohol- and drugrelated disorders in ED patients is as high as $20 \% .^{31-33}$ Some series indicate that over half of all injury victims have positive screening tests for drugs or alcohol, ${ }^{15,34,35}$ and the current study showed that $49 \%$ of injured drivers who had blood alcohol testing had detectable ethanol levels and $36.4 \%$ were legally impaired. Clearly, alcohol is a major concern for emergency care providers.

We feel strongly that emergency physicians and nurses should collaborate in ongoing and future efforts to increase the conviction rate of impaired drivers. We also feel that the ED is an ideal place to screen for substance-related problems and to initiate interventions to control these before serious accidents occur. Simple screening tests like the CAGE Questionnaire can identify ED patients at risk ${ }^{36}$ and, although referral for more comprehensive treatment is of- ten required, some patients will benefit from a brief motivational interview in the ED. ${ }^{37,38}$ ED-based screening and brief intervention programs are particularly important for impaired drivers because drinking-driving behaviour also puts others at risk of severe injury.

\section{Conclusions}

Relatively few hospitalized impaired drivers are convicted of impaired driving or other criminal code offences. If conviction reduces the risk of future injury to the involved individual or to others, then our findings support the need for legislation like that seen in other countries to streamline the process of charging and convicting impaired drivers who are treated in hospitals and EDs. Emergency providers should also consider introducing substance misuse screening and intervention programs to prevent future medicaland injury-related adverse outcomes.

Acknowledgement: Dr. Riyad Abu-Laban is supported by a Clinical Scholar Award for the Michael Smith Foundation for Health Research.

Competing interests: None declared.

\section{References}

1. National Highway Traffic Safety Administration. US Department of Transportation. Traffic safety facts: overview, 1998. Washington (DC): National Highway Traffic Safety Administration; 1999.

2. Statistics Canada. Causes of death, 1998. Shelf tables. Cat no 84F0208XPB, 2001.

3. Mayhew DR, Brown SW, Simpson HM. The alcohol-crash problem in Canada: 2001. Ottawa: Traffic Injury Research Foundation; 2003.

4. National Highway Traffic Safety Administration (NHTSA) notes. The economic cost of motor vehicle crashes, 1994 [published erratum appears in Ann Emerg Med 1997;29(2):310]. Ann Emerg Med 1996;28(6):711-2.

5. Waller PF, Stewart JR, Hansen AR, Stutts JC, Popkin CL, Rodgman EA. The potentiating effects of alcohol on driver injury [abstract]. JAMA 1986;256:1461-6.

6. Zador PL. Alcohol-related relative risk of fatal driver injuries in relation to driver age and sex. J Stud Alcohol 1991;52:302-10.

7. Maull KI, Kinning LS, Hickman JK. Culpability and accountability of hospitalized injured alcohol-impaired drivers. JAMA 1984;252:1880-3.

8. Colquitt M, Fielding LP, Cronan JF. Drunk drivers and medical and social injury. N Engl J Med 1987;317:1262-6.

9. Soderstrom CA, Birschback BS, Dischinger PC. Injured drivers and alcohol use: culpability, convictions and pre- and post-crash driving history. J Trauma 1990;30:1208-14.

10. Runge JQ, Pulliam CL, Carter JM, Thomason MH. Enforcement of drunken driving laws in cases involving injured intoxicated drivers. Ann Emerg Med 1996;27:66-72.

11. Cydulka RK, Harmody MR, Barraski A, Fallon W, Emerman CL. Injured intoxicated drivers: citation, conviction, referral, and recidivism rates. Ann Emerg Med 1998;32:349-52.

12. Krause KR, Howells GA, Bair HA. Prosecution and conviction 
of the injured intoxicated driver. J Trauma 1998;45:1069-73.

13. Mattsson S, Eriksson A, Sjorgren H. Conviction rates among hospitalized DUI/DWI drivers. J Traffic Med 2000;28:21-4.

14. Evett JK, Finley CJ, Nunez A, Britt LD, Huff JS. Judicial outcome for the intoxicated driver admitted to a regional trauma center. Acad Emerg Med 1994;1(3):254-7.

15. Fantus RI, Zautche JL, Hichey PA. Driving under the influence : a Level I Trauma Center's experience. J Trauma 1991;31:1517-20.

16. McLaughlin JG, Smith RJ, Mattice CR, Scholten DJ. Hospitalization and injury influence on the prosecution of drunk drivers. Am Surg 1993;59(8):484-8; discussion 488-9.

17. Rehm CG, Nelson J, MacKenzie D, Ross SE. Failure of the legal system to enforce drunk driving legislation effectively. Ann Emerg Med 1993;22:1295-7.

18. Barillo DJ. Arrest and conviction of injured intoxicated drivers in Eastern Pennsylvania. Accid Anal Prev 1993;25:635-9.

19. Wilson RJ, Fang M. Do collision factors predict legal outcomes for injured drinking drivers? Proceedings of the 16th International Conference on Alcohol, Drugs and Traffic Safety, Montreal, Aug 4-9, 2002.

20. Linguanti F. Trends in impaired driving charges and outcomes in British Columbia, 1989 to 1997. Insurance Corporation of British Columbia, Impaired Driving Road Safety Strategic Initiatives, 1998.

21. Government of British Columbia. Drinking and driving issues and strategies in British Columbia: Discussion Paper, June 2003. Available: www.pssg.gov.bc.ca/legislation/drinking-driving/idrdiscussion-paper.pdf (accessed 2004 Jan 20).

22. Ministry of Attorney General. Traffic Services Study, final report. Safe roads, safe communities. Victoria (BC): Public Safety and Regulatory Branch, Police Services Division; 2000.

23. Jonah B, Yuen L, Au-Yeung E, Paterson D, Dawson N, Thiessen R, et al. Front-line police officers' practices, perceptions and attitudes about the enforcement of impaired driving laws in Canada. Accid Anal Prev 1999;31(5):421-43.

24. Solomon R, Chamberlain E, DeCicco N, Hurst S, Kraatz J. Taking back our roads: federal legislative reform agenda 2001. MADD Canada; 2001. [Unpublished report, available from Prof. Robert Solomon, Faculty of Law, University of Western Ontario, London ON N6A 3K7.]

25. Ross HL, Gonzales P. Effects of license revocation on drunkdriving offenders. Accid Anal Prev 1988;20:379-91.

26. Transport Canada. Road Safety Vision 2010 - 2001 Update. Available: www.tc.gc.ca/roadsafety/vision/2001/menu.htm (accessed 2004 Jan 21).

27. Vézina L. The Quebec Alcohol Ignition Interlock Program: impact on recidivism and crashes. Proceedings of the 16th International Conference on Alcohol, Drugs and Traffic Safety, Mon- treal, Aug 4-9, 2002.

28. Voas RB, Marques PR, Tippetts AS, Beirness DJ. The Alberta Interlock Program: the evaluation of a province-wide program on DUI recidivism. Addiction 1999;94(12):1849-59.

29. Beirness DJ, Robertson RD. Best practices for alcohol interlock programs: findings from two workshops. Proceedings of the 16th International Conference on Alcohol, Drugs and Traffic Safety, Montreal, Aug 4-9, 2002.

30. Brubacher JR, Mabie A, Ngo M, Buchanan J, Abu-Laban RB, Shenton T, et al. Documentation of substance abuse in a Canadian tertiary care emergency department patient population [abstract]. Can J Emerg Med 2003;5(3):195.

31. Whiteman PJ, Hoffman RS, Goldfrank LR. Alcoholism in the emergency department: an epidemiologic study. Acad Emerg Med 2000;7:14-20.

32. McCaig L, Greenblatt J. Preliminary estimates from the Drug Abuse Warning Network: preliminary estimates of drug-related emergency department episodes. SAMHSA. Substance Abuse and Mental Health Services Administration, Office of Applied Studies. Advance Report \#17. August 1996. Available: http://ncadi.samhsa .gov/govstudy/AR017/ (accessed 2004 Jan 21).

33. D'Onorfio G: Screening and brief intervention for alcohol and other drug problems: What will it take? Acad Emerg Med 2000; 7:69-71.

34. Rivara FP, Mueller BA, Fligner CL, Luna G, Raisys VA, Copass M, et al: Drug use in trauma victims. J Trauma 1989;29: 462-70.

35. Parran TV, Weber E, Tasse J, Anderson B, Adelman C. Mandatory toxicologic testing and chemical dependence consultation follow-up in a level one trauma center. J Trauma 1995;38:278-80.

36. D'Onofrio G, Bernstein E, Bernstein J, Woolard RH, Brewer PA, Craig, SA, et al: Patients with alcohol problems in the emergency department, part 1: improving detection. SAEM Substance Abuse Task Force. Society for Academic Emergency Medicine. Acad Emerg Med 1998;5(12):1200-9.

37. Gentilello LM, Rivara FP, Donovan DM, Jurkovitch GJ, Daranciang E, Dunn CW, et al. Alcohol interventions in a trauma center as a means of reducing the risk of injury recurrence. Ann Surg 1999;230:473-80; discussion 480-3.

38. D'Onofrio G, Degutis LC. Preventive care in the emergency department: screening and brief intervention for alcohol problems in the emergency department: a systematic review. Acad Emerg Med 2002;9:627-38.

Correspondence to: Dr. R. Purssell, Emergency Department, Vancouver Hospital, 855 West 12th Ave., Vancouver BC V5Z 1M9; 604 875-5242, fax 604 875-4872,rpurssel@vanhosp.bc.ca 